\title{
The relationship of the geological framework to the Quaternary aquifer system in the Sava River valley (Croatia)
}

\author{
Željka Brkić \\ Croatian Geological Survey, Department of Hydrogeology and Engineering Geology, Sachsova 2, 10000 Zagreb, Croatia; (zeljka.brkic@hgi-cgs.hr)
}

doi: 10.4154/gc.2017.12

\section{Article history:}

Manuscript received February 02, 2017 Revised manuscript accepted May 05, 2017 Available online October 31, 2017
Keywords: lithological composition, alluvial fan, Quaternary aquifer, hydrogeological characteristics, Sava River, Croatia

\begin{abstract}
Data from approximately 500 boreholes and an additional 40 wells for which there is a plausible range of data, facilitate description of the geometry of the Quaternary aquifer and its characteristics respectively, and pretension of the elements of the conceptual hydrogeological model in the Sava River valley. The aquifer heterogeneity is caused by tectonic activity and the depositional environments of the sediments within the valley. In the wider Zagreb area, gravel is the dominant component of the aquifer. Downstream from Zagreb, the aquifer is composed mainly of sand with sporadic intercalations of gravel. An admixture of silt and clay is not uncommon within the sand. The exceptions are alluvial fans that were formed by the right tributaries of the Sava River; gravel with sand is dominant in their lithological composition. The best hydrogeological properties of the aquifer system were registered in the vicinity of the Sava River, so all large pumping sites are located close to the river. The Quaternary aquifer is the main source of the water supply in the Sava River valley.
\end{abstract}

\section{INTRODUCTION}

The geological framework is defined by the form and development of the valley structure as well as the lithology and depositional environments within it. Structural deformation, volcanism and erosion determine the geometry of the mountains as well as the extent and depth of the valley (HOLLETT et al., 1991). These structures and the lithology strongly control the permeability and storage characteristics of the deposits.

The Sava River valley is situated in the southwestern (SW) part of the Pannonian Basin (Fig. 1). In its wider area, two principal topographic features represent the surface expression of the geological framework: the mountain ranges and the narrow intermountain valley. Mt. Medvednica and Mt. Moslovačka gora as well as the Slavonian Mountains (Mt. Papuk, Mt. Krndija, Mt. Psunj, Mt. Požeška and Mt. Dilj) are situated at the north end of the Sava River valley. At the southern end, the valley is bounded by Mt. Žumberak-Samoborsko gorje in Croatia as well as Mt. Prosara, Mt. Motajica and Mt. Majevica in Bosnia and Herzegovina. These mountains were uplifted during the Pliocene epoch and Quaternary period (PAVELIĆ, 2001; ŠPARICA et al., 1972a,b; 1983; ŠPARICA \& BUZALJKO, 1984; ŠPARICA, 1987).

The Sava River valley is filled with Neogene and Quaternary sediments. Along the southern margin, the maximum depth to

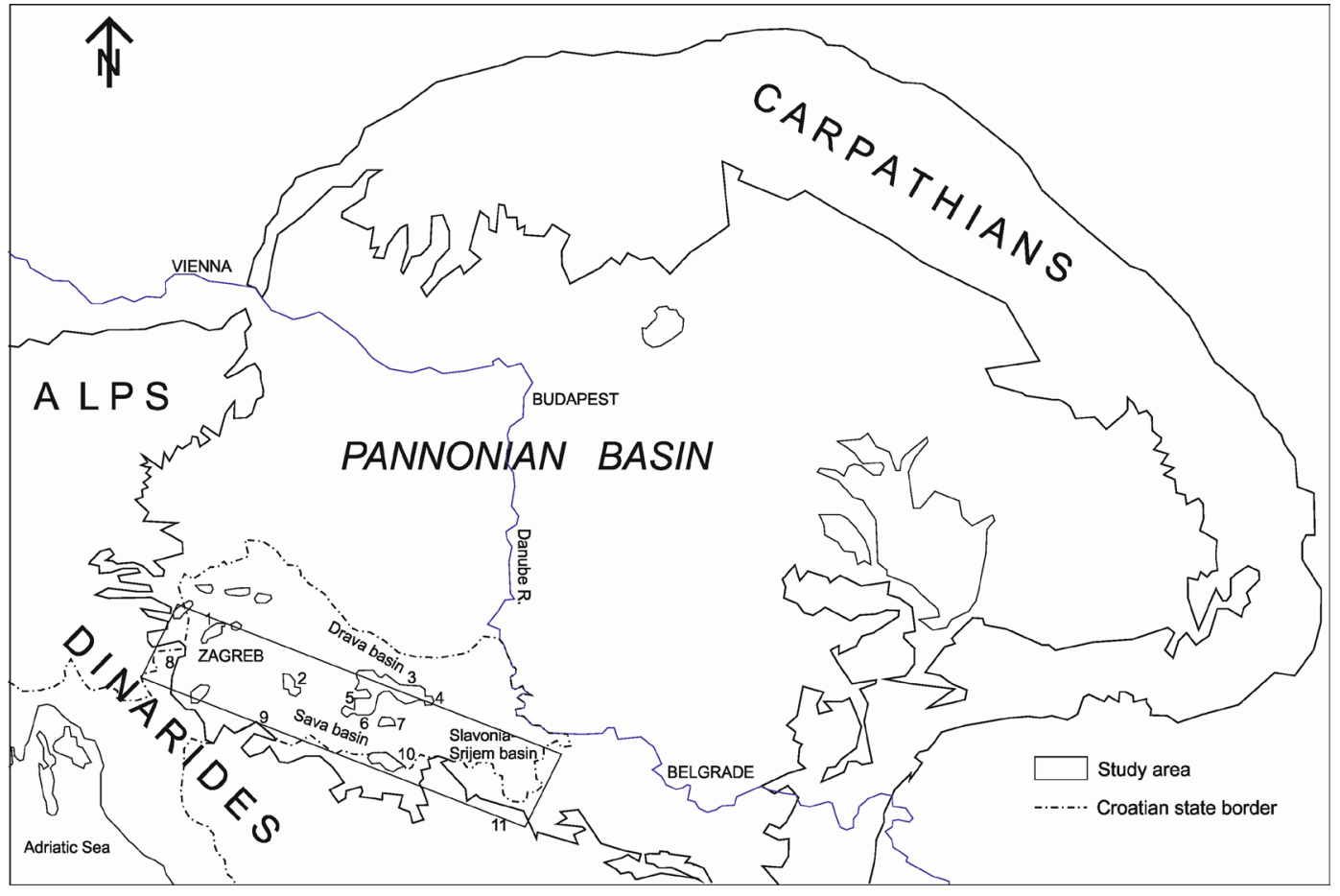

Figure 1. Location of the Pannonian basin showing the position of the Sava basin and Sava River valley (simplified after Horváth, 1993). Legend: 1 - Mt. Medvednica, $2-$ Mt. Moslovačka gora, 3 - Mt. Papuk, 4 - Mt. Krndija, 5 - Mt. Psunj, 6 - Mt. Požeška, 7-Mt. Dilj, 8 Mt. Žumberačko-Samoborsko gorje, 9 - Mt. Prosara, 10 - Mt. Motajica and 11 - Mt. Majevica 
the pre-Miocene deposits reaches $4000 \mathrm{~m}$ (PRELOGOVIĆ, 1975; HERNITZ, 1983). The older Quaternary boundary (Lower Pleistocene-Middle Pleistocene) is defined by the conditional E-log marker Q' (URUMOVIĆ et al., 1976). According to URUMOVIĆ et al. (1976), Q' represents the most imposing lithostratigraphic boundary and can be tracked as a regional discontinuity during deposition. Above this marker, the coarse-grained sediments, gravel and sand, were deposited, while underlying sediments are silt and clay. The Q' marker lies at a maximum depth of $300 \mathrm{~m}$ (HERNITZ, 1983). The groundwater that accumulates in the sandy and gravelly aquifers above marker Q' is the main source of the water-supply for the whole region.

The aim of this paper is to determine the geometry of the Quaternary aquifer system in the Sava River valley, as well as highlighting its lithological and hydrogeological characteristics. Data from approximately 500 boreholes and an additional 40 wells have been collected for the purposes of this research. The boreholes are unevenly distributed in the valley, but most of them are in the wider area of the Zagreb aquifer. Data from the boreholes were used to update the hydrogeological knowledge of the valley. A series of lithological cross-sections are presented in this study, and new groundwater level data were used to improve the definition of the conceptual hydrogeological model.

\section{GEOLOGICAL STRUCTURES OF THE SOUTH- WESTERN PART OF THE PANNONIAN BASIN}

The geodynamic evolution of the Pannonian Basin (PB) has been discussed in many detailed and comprehensive studies (STEGENA et al., 1975; ROYDEN et al., 1983; KÁZMER \& KOVÁCS, 1985; ROYDEN \& HORVÁTH, 1988; RATSCHBACHER, 1991; CSONTOS et al., 1992; HORVATH, 1993; DECKER \& PERESSON, 1996; PERESSON \& DECKER, 1997). The southern PB, which extends from eastern Slovenia through northern Croatia and from northern Bosnia to Serbia, as well as its evolution, is de-

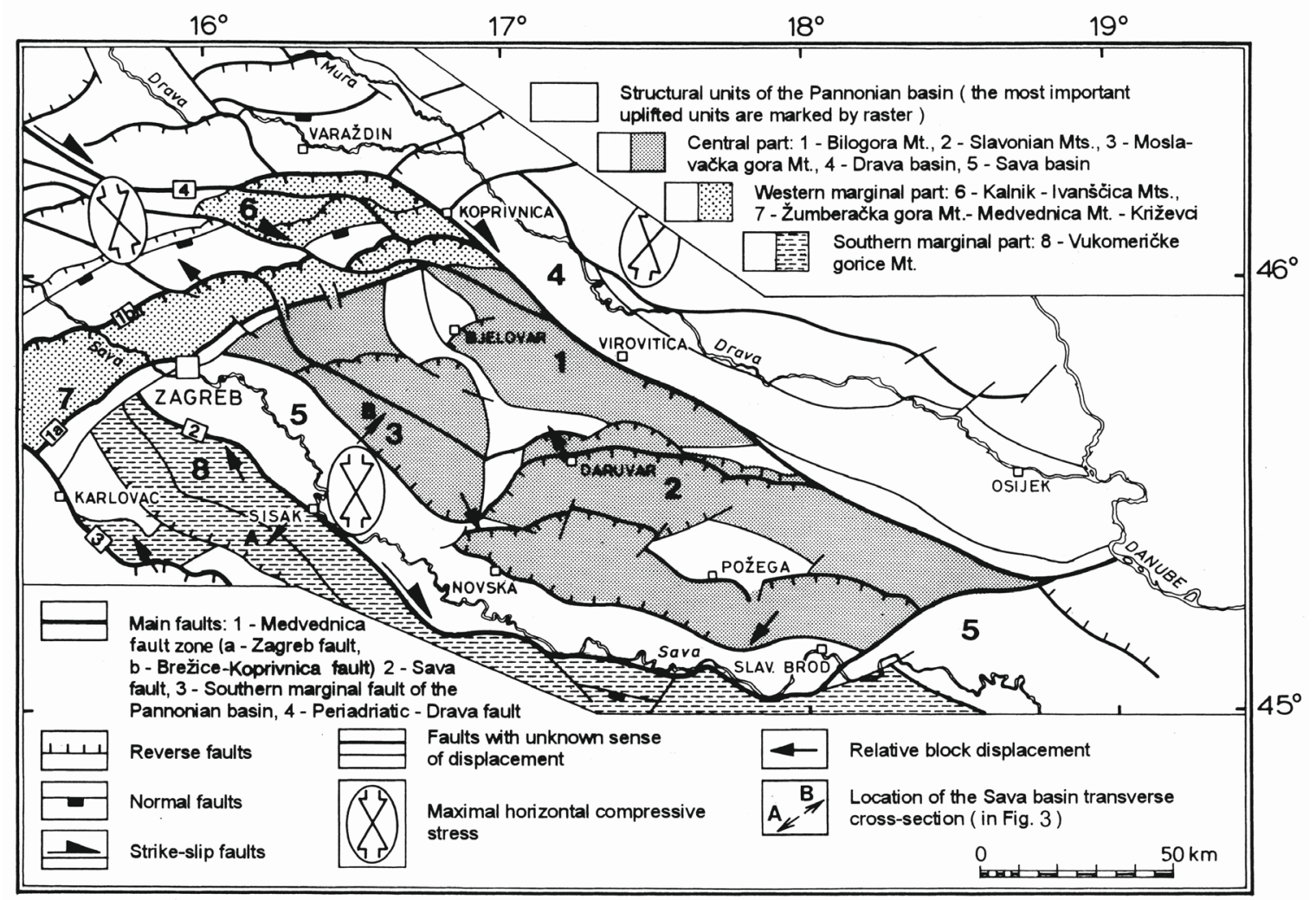

Figure 2. Classification of structures and faults (Prelogović et al., 1998).

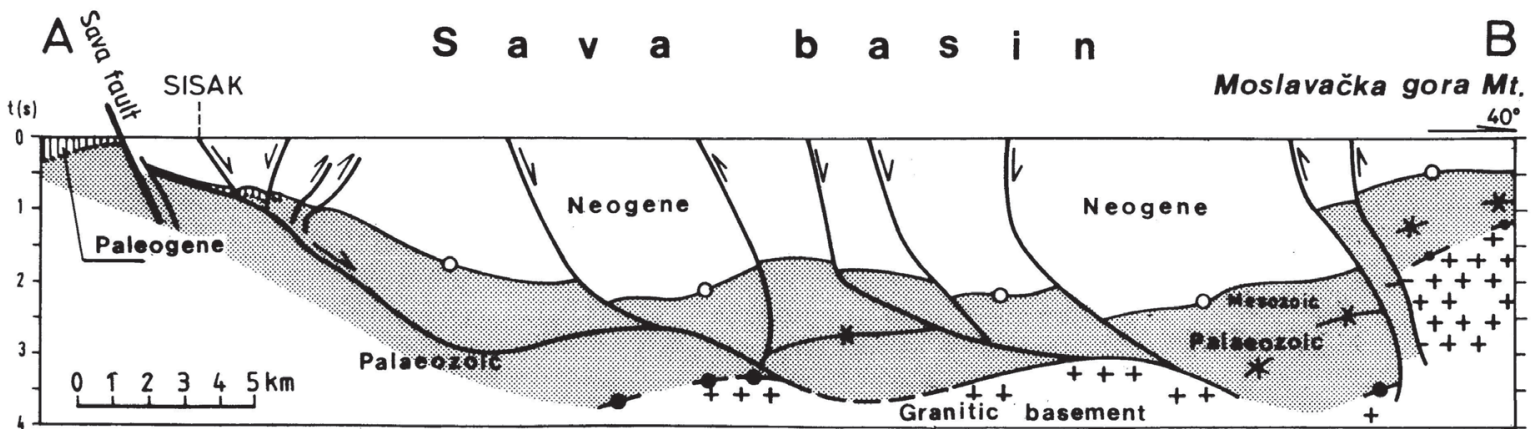

$\square$ Neogene basement

* Major seismic reflection within the Palaeozoic rocks
Inferred top of granite rocks

Faults

Figure 3. Cross-section through the Sava basin (Prelogović et al., 1998). 
scribed by TARI \& PAMIĆ (1998), PRELOGOVIĆ et al. (1998), VELIĆ (1983). The PB includes the Drava River basin in the north and the Sava River and Slavonija-Srijem basins in the south of northern Croatia.

In this paper, the focus is on the Sava River basin.

The evolution of the southwestern Pannonian Basin occurred during continued convergence between the Adriatic plate and the Southern Alps/Dinarides. According to PRELOGOVIĆ et al. (1998), the most important transcurrent faults that were active in this stress field are the Periadriatic fault and its extension in the Drava fault and the fault along the margin of the Dinarides, which here is referred to as the southern marginal fault of the PB (Fig. 2). Between these faults, transpression occurred during the Pliocene and Quaternary. Highlighted compressional structures were formed between the Sava and the Drava faults - the Žumberak-Medvednica Mountains structural unit, the Slavonian Mountains unit and the Moslavačka gora Mountains unit. Displacement and rotation of the uplifted mountain ranges reduced the area of the surrounding basins.

The Sava fault zone is illustrated by the transverse crosssection of the Sava basin (PRELOGOVIĆ et al., 1998). An asymmetric basin was formed during the Miocene epoch. Several faults within the basin as well as the SW boundary faults were reactivated as reverse faults during compression in the Pliocene and Quaternary (Fig. 3).

PAVELIC (2001) indicated that the evolution of northern Croatia and northern Bosnia, as a part of the marginal zone of the Pannonian Basin, is interpreted as resulting from continental rifting. The Sava basin, together with the Drava basin, Požega valley, and the trough along the southern margin of Mt. Motajica in northern Bosnia, form an elongated half-graben due to tectonic subsidence along listric and strike-slip faults.

The Pliocene epoch and most of the Quaternary period represented a new phase of basin evolution characterized by a transition towards overall compression and structural inversion across the entire PB (HORVÁTH \& CLOETINGH, 1996). In the North Croatian Basin, this was marked by the formation of many compressional structures (Fig. 4), mostly by inversion of pre-existing listric normal faults and uplift of basement blocks to form the present mountains in the area (e.g., Mts. Papuk, Psunj, Požeška, Moslavačka, etc.). This period was characterized by strong vertical movements (PAVELIĆ, 2001).

\section{DATA AND METHODS}

Borehole and site investigation data were collected from different sources, but most of them are from the data base of the Croatian Geological Survey as well as from geotechnical and civil engineering companies (eg. Geofizika, Geotehnika). Forty borehole records were selected for construction of lithological profiles throughout the Sava River valley. The boreholes that are located along the Sava River were used for a longitudinal lithological profile, while a series of boreholes perpendicular to the valley direction was grouped to display cross-sections of the valley. The cross-sections show the lithology present in each borehole and correlations between boreholes. Geophysical investigations were also undertaken to define the boundaries, shape and depths of the aquifers.

The boundaries of the aquifer layers with different hydraulic conductivity values were identified using pumping test data and grain-size analysis of non-coherent deposits.

The lithological composition of the overlying layers is displayed based on soil data for the first $4 \mathrm{~m}$ of the overlying layer depth. Data were collected from the Faculty of Agriculture of the University of Zagreb (VIDAČEK et al., 2002).

\section{RESULTS AND DISCUSSION}

\subsection{Geometry and lithological characteristics of the Quaternary aquifer}

The boundary between the Pliocene and Pleistocene epochs has not been defined with confidence (BAČANI et al., 1999). Most researchers have concluded that the transition from the Pliocene to the Pleistocene was gradual. It is believed that climatological, environmental and lithological continuity exists from the Pliocene to the Pleistocene (MAGAŠ, 1986). Because of the constant lowering of the Sava Basin, the type of sedimentation remained the same, mostly from marshes, and the mineral composition changed only partially, suggesting a change in areal distribution (An. ŠIMUNIĆ et al., 1973).

Palaeoclimate conditions in the Middle and Upper Pleistocene played the main role in the transport and deposition of clastic sediments. Alternatively, during the warm and humid periods, a large amount of coarse-grained materials was transported by surface waters and deposited in the valleys. In contrast, during the cold and dry periods, fine-grained materials were transported mostly by wind and deposited in the lakes and marshes. The main volume of permeable sediments of which the aquifers are composed was deposited during the Middle Pleistocene.

The vertical and lateral spreading of the aquifers in the Sava River valley was caused by neotectonic movements and the formation of the geological structures in the southwestern part of the Pannonian Basin.

The geological and hydrogeological characteristics of the Quaternary sediments in the Sava River valley are quite different from those of the Drava River valley, where the Drava aquifer system is composed of material of mostly the same origin (Alps and sporadic surrounding mountains). Additionally, in the Drava

g)

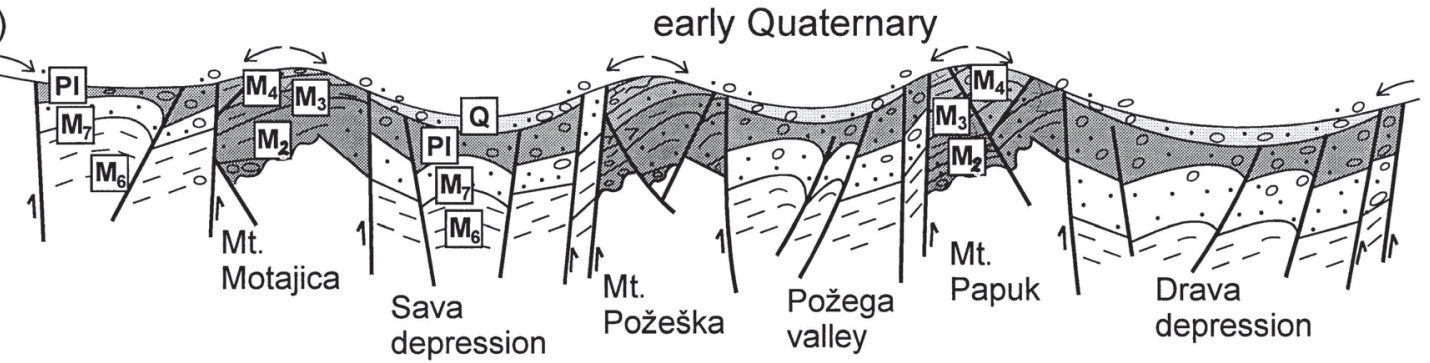

Figure 4. Model of the evolution of the Slavonian Mountains and northern Bosnia - early Quaternary (Pavelić, 2001). 


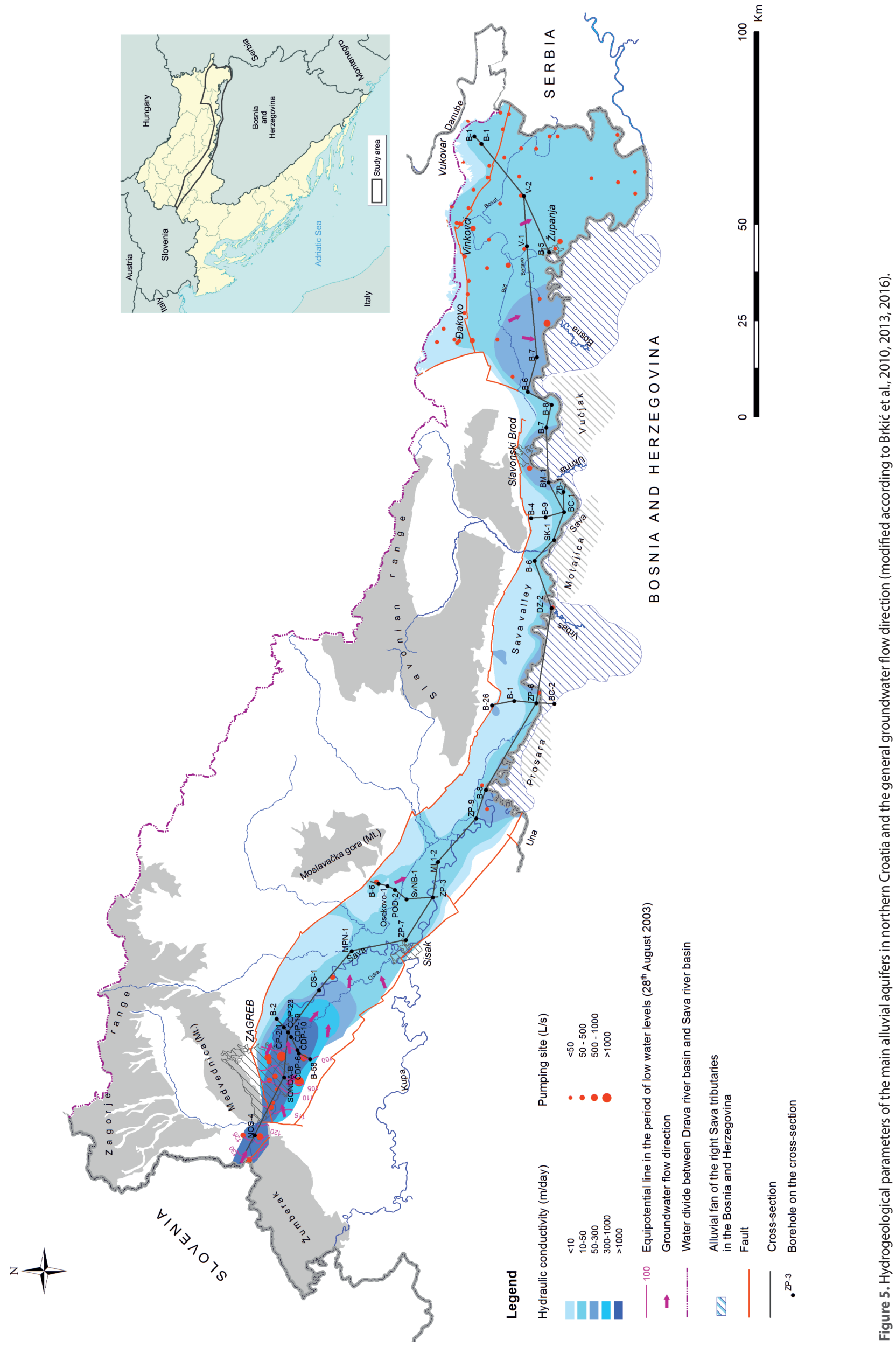




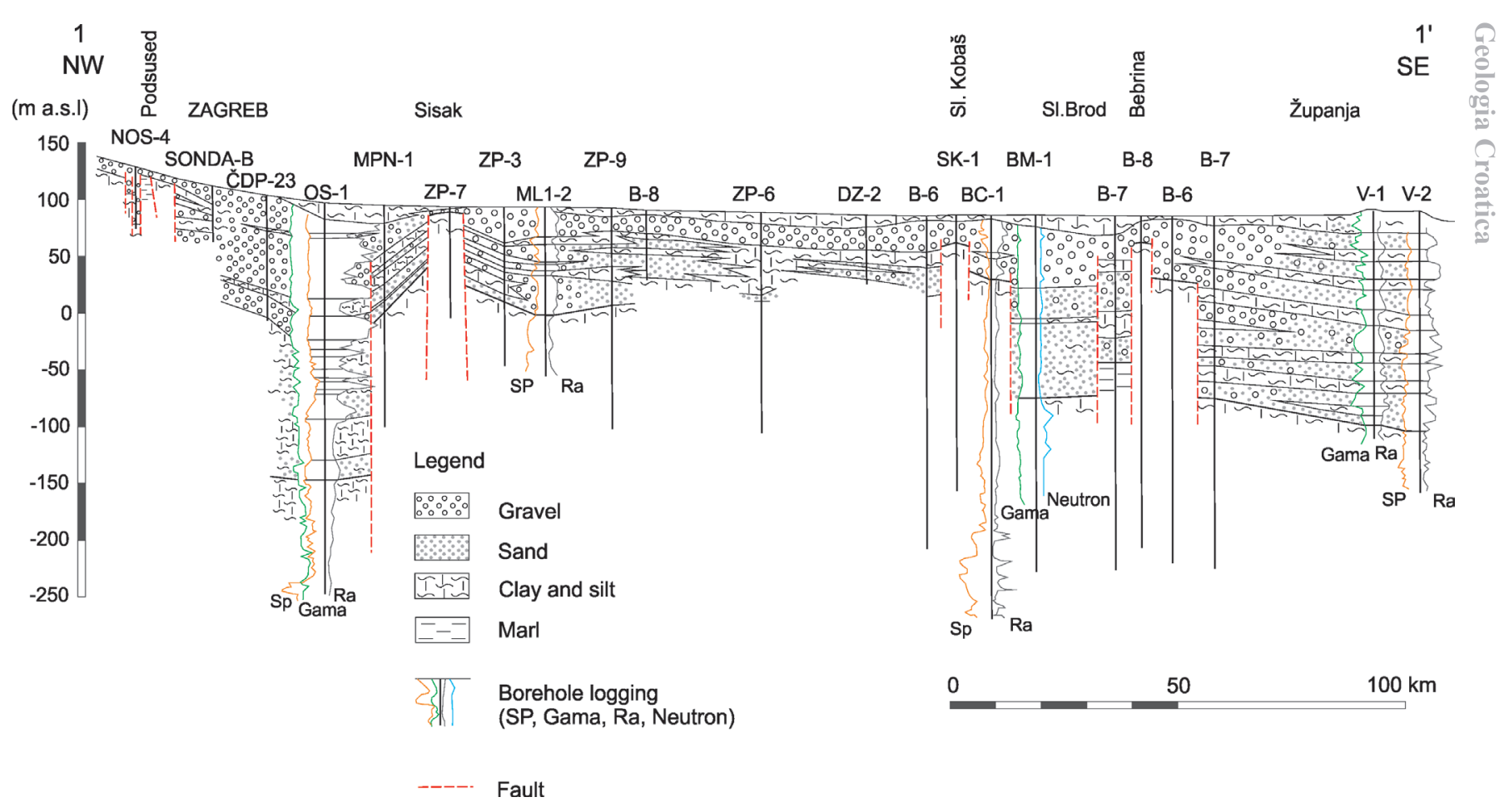

Figure 6. Longitudinal lithological cross-section of the Quaternary aquifer through the Sava River valley.

River valley, the thickness of the Quaternary aquifer gradually increases from west to east as the size of the gravel pebbles and sand grains decreases (BABIĆ et al., 1978; URUMOVIĆ et al, 1994).

In the late Pleistocene and early Holocene, tectonic movements were renewed along the edges of the Medvednica and Žumberak mountains, causing a further lowering of lowland terrain and the formation of the Sava River valley in the narrow sense (ŠIKIĆ, 1995). VELIĆ \& SAFTIĆ (1996) stated that the Sava River broke through from the Alps at the beginning of the last warming period (i.e. prior to $\sim 10.000$ years ago). Lowering of the terrain enabled the Sava River flow to break through the Medvednica-Žumberak barrier so that water ran off to the southeast. As the water flow slowed down, it lost energy and began to deposit the fluvial sediments. The coarse-grained sediments were deposited in the wider Zagreb area. Downstream from Zagreb, the prevailing sediments are fine- to medium-grained sand, and the major occurrences of the coarse sediments exist only at the mouths of its right tributaries the Una, Vrbas, Ukrina, Bosna and Drina Rivers (BRKIĆ \& BIONDIĆ, 2000; CAPAR et al., 1994; URUMOVIĆ \& MIHELČIĆ, 2000) (Fig. 5).

In the initial western part of the Sava River valley, the Quaternary aquifer is very thin (Fig. 6). It is composed mainly of gravel with boulders that reach up to $300 \mathrm{~mm}$ in size. The aquifer bedrock is composed of marl of Miocene age. According to petrographic composition, the origin of the gravel is tied to the Alps as well as to Mt. Samoborsko gorje (part of the Mt. Žumberak) and Mt. Medvednica (CRNKOVIĆ \& BUŠIĆ, 1970; Al. ŠIMUNIĆ et al., 1988, VELIĆ \& SAFTIĆ, 1991). The size of the gravel pebbles decreases from west to east and from the surface to depth as the proportion of smaller fractions increases. Along the edges of the Samoborsko gorje hills, there is no gravel from the Sava River; in this area, the deposits originated from the Bregana, Gradna and Rakovica streams.
The Quaternary aquifer reaches a thickness of $54 \mathrm{~m}$ in the Strmec area (borehole NOS-4 on Fig. 6). The deposits of the Middle Pleistocene age were found in the depth interval from 9 to 54 m (VELIĆ \& SAFTIĆ, 1991). Among the gravel pebbles, there is no limestone; on this basis, it was concluded that the sediments came from the surrounding hills. The sediments were deposited in an isolated local geological structure (borehole NOS-4 on Fig. 6) that is oriented approximately northeast-southwest. The structure is filled with sediments of Middle Pleistocene age that in this location have been ,spared" from erosion. Upstream and downstream of the structure, erosion of these sediments was expressed and manifested by the deposition of the Holocene gravel directly onto the Miocene sediments. The origin of the Holocene gravel is related mainly to the Alps.

In the area of the geological structure known as ,Podsusedski prag", (downstream of borehole NOS-4 on Fig. 6), where the underground hydraulic connection between Samobor and the Zagreb basin is limited to a narrow zone barely $1.5 \mathrm{~km}$ wide, the aquifer thickness is a maximum of $8 \mathrm{~m}$. East of this structure, the Quaternary aquifer thickness increases, reaching a maximum of approximately $100 \mathrm{~m}$ in the southeastern part of the Zagreb basin (borehole ČDP-23 on Fig. 6 and Fig. 7). Downstream of the structure „Podsusedski prag”, in the western part of Zagreb, deposits of the Middle Pleistocene have been identified in the depth interval from 10.35 to $24.3 \mathrm{~m}$ (VELIĆ \& DURN, 1993). They consist mainly of grey sand with a high proportion of the clay-silt sediments that VELIĆ \& DURN (1993), state were deposited during conditions of rapid sedimentation in an aqueous environment of low energy.

Downstream from Zagreb, at Prevlaka and Oborovo (borehole OS-1 on Fig. 6), deposits of the Middle Pleistocene age occur in the depth interval from 20 to $256 \mathrm{~m}$ (SOKAČ, 1978; HERNITZ et al., 1981). There are several sandy gravel layers within the Middle Pleistocene deposits. The clay layers are smaller and thinner, and the grain size in the sandy gravel layers decreases 


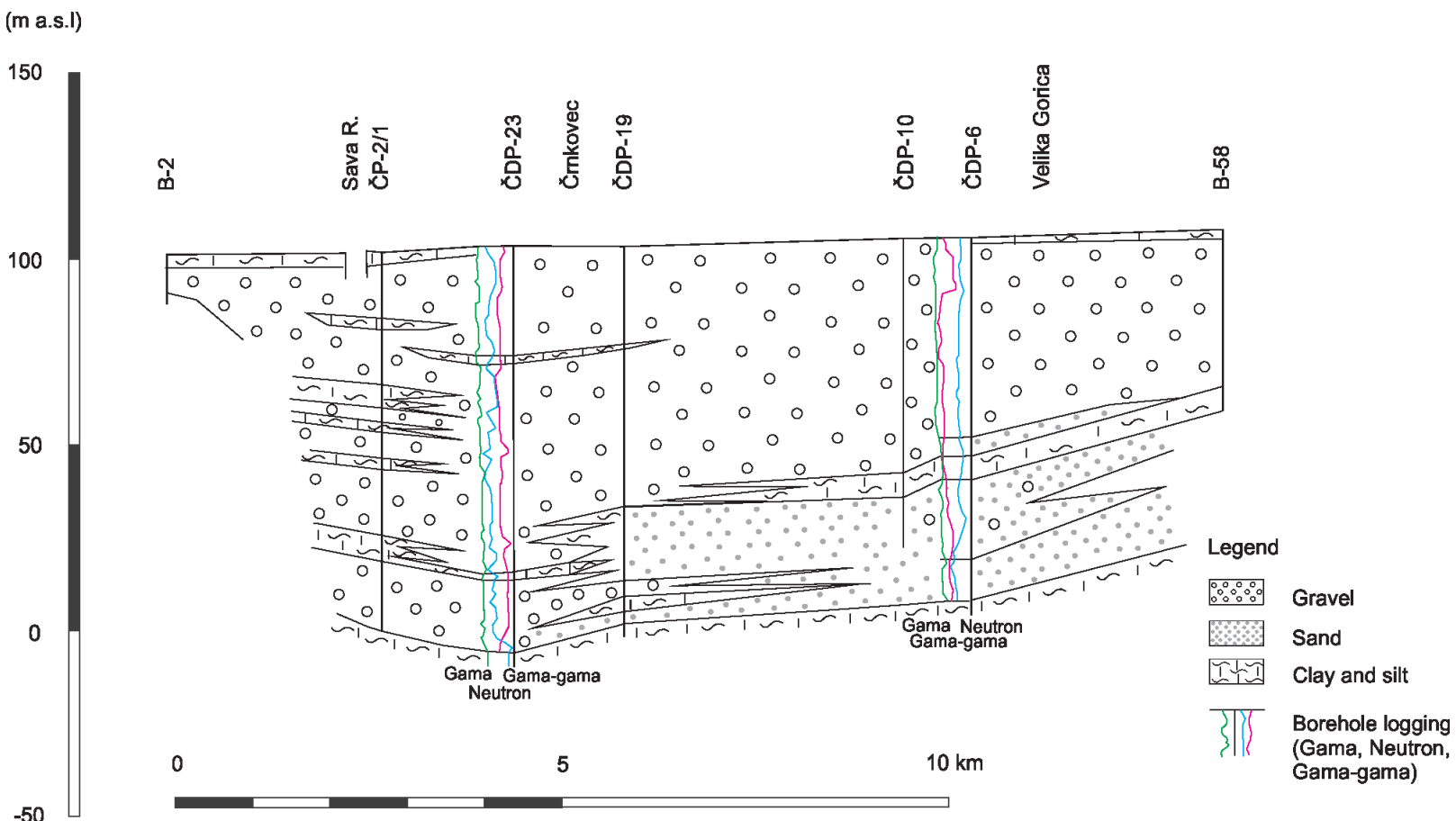

Figure 7. Lateral lithological cross-section of the Quaternary aquifer downstream of Zagreb.

with depth. From the surface to a depth of $150 \mathrm{~m}$, fine to medium pebbles with a diameter of 10-20 $\mathrm{mm}$ dominate, but above $50 \mathrm{~m}$, pebbles can reach a diameter of $80 \mathrm{~mm}$.

The sediments of Lower Pleistocene age were deposited below $256 \mathrm{~m}$. They are represented by layers of clay and fine- grained sand. Within the clay layers, plant remains were registered. As such, they represent the bedrock of the aquifer system.

It should be noted that An. ŠIMUNIĆ \& BASH (1975) and Al. ŠIMUNIĆ et al. (1988) considered that the Middle Pleistocene sediments in this area are situated below a depth of $75 \mathrm{~m}$ and are

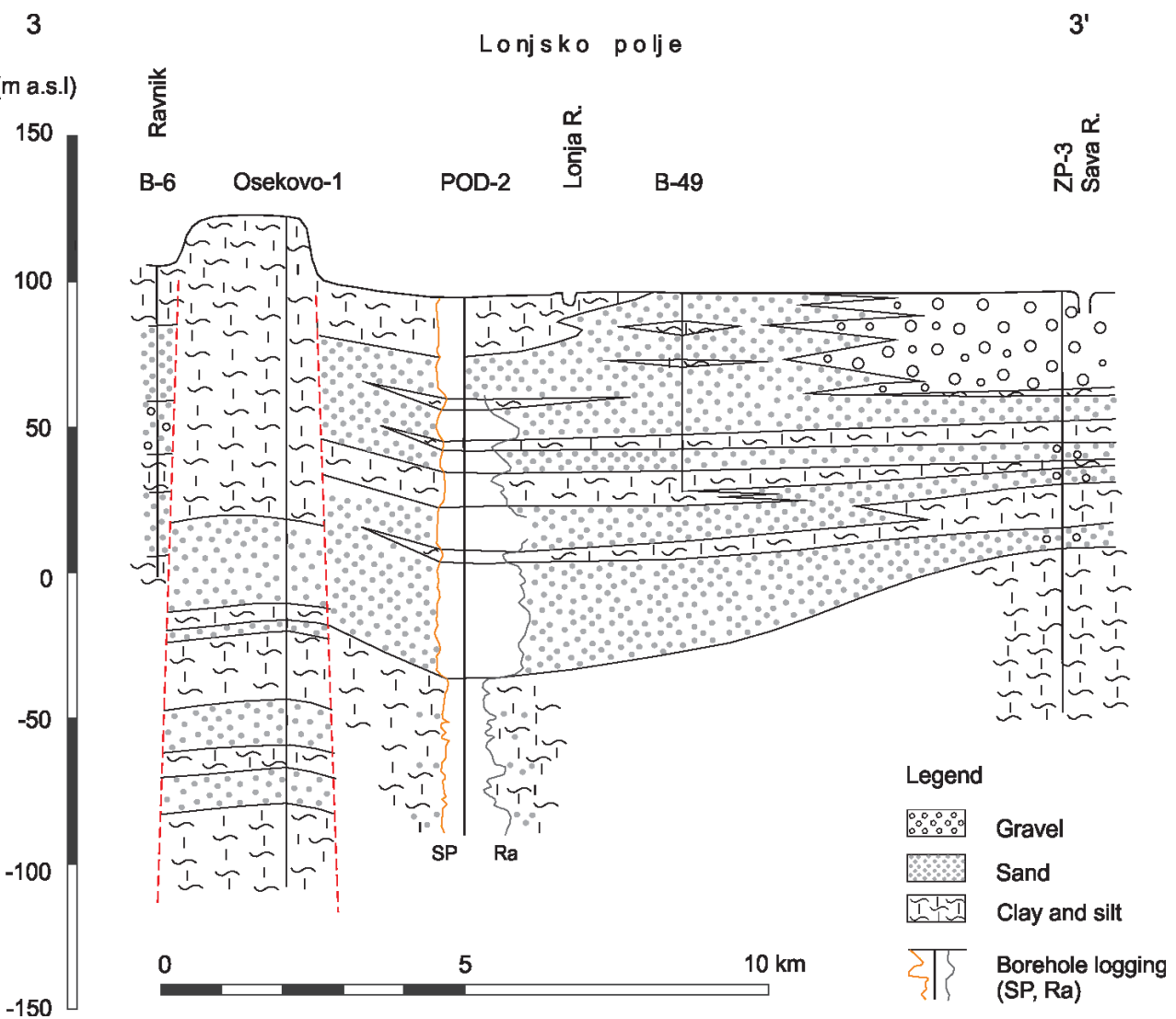

Figure 8. Lateral lithological cross-section of the Quaternary aquifer downstream of Sisak. 
overlain by sediments of Late Pleistocene age. Based on the mineralogical and petrographic composition of the Upper Pleistocene sediments, these authors concluded that most of the detrital material came from Mt. Medvednica and the neighbouring mountains and a small part from the Alps. They also concluded that transport from nearby regions occurred during interstadial periods, while the alpine influence was significant during stadial periods and under the influence of air currents.

Downstream from Dubrovčak (between boreholes OS-1 and MPN-1 on Fig. 6), the thickness of the aquifer system gradually decreases as it approaches the geological structure known as "Sisački prag". This structure is located along the southern boundary of the Sava River valley and the Sava fault, along which the lowering of the basin occurred (Fig. 3). The aquifer is extremely thin here (borehole ZP-7 on Fig. 6), reaching only $5 \mathrm{~m}$, and consists of sand with much clay and silt.

Downstream from Sisak, the Quaternary aquifer is composed of generally fine to medium-grained sand. The gravel was deposited near the Sava River (Fig. 8). The maximum thickness of the Quaternary aquifer is approximately $100 \mathrm{~m}$ in the area of the Lonjsko polje (borehole ML1-2 on Fig. 6 and POD-2 on Fig. 8). The geological structure Stružec-Osekovo was uplifted between the Lonjsko polje and Ravnik (Fig. 8). Below approximately 100-metre thickness of clay-silt sediments, sandy layers occur that could be associated with coarse-grained sediments at both of these locations.

Between Sisak and Županja, larger quantities of gravel are related exclusively to the alluvial fans that have been formed by the coarse-grained sediments of the right tributaries of the Sava River (the Una, Vrbas, Ukrina and Bosna), and to much lesser extent the left tributaries (the Ilova, Pakra, Sloboština, Šumetlica and Orljava) (Figs. 5 and 6). The mineralogical and petrographic composition of sediments in the southern alluvial fans shows that they mostly represent eroded material from the Bosnian mountains and that the sediments came partially from alpine distribution areas. Due to falling river energy, the coarse-grained material was deposited along the southern edge of the Sava and Slavonia-Srijem basin, while the finer material dominates to the north and is often absent.

The layer thickness of the coarse-grained material is quite uneven. The disturbed continuity of the layers is caused by the manner of deposition and by neotectonic movements. The basin evolution during the Pliocene and most of the Quaternary was characterized by a transition towards overall compression and structural inversion across the entire Pannonian Basin (HORVÁTH \& CLOETINGH, 1996). It resulted in uplift and reverse faulting of the massifs towards the north (JAMIČIĆ, 1983, 1995; ŠPARICA \& PAMIĆ, 1986; PRELOGOVIĆ et al., 1995, 1998; HORVÁTH \& CLOETINGH, 1996; TARI \& PAMIĆ, 1998). The reverse faulting was generated by pressure from the south, resulting in an anticlockwise block rotation (JAMIČIĆ, 1983; MÁRTON et al., 1999). In the North Croatian Basin, this movement resulted in the formation of many compressional structures, mostly by the inversion of pre-existing listric normal faults and uplift of basement blocks to form the present mountains in the area (e.g., Papuk, Psunj, Požeška gora, Moslavačka gora, etc.) (PAVELIĆ, 2001). During the Quaternary, important vertical movements occurred - Mt. Papuk was uplifted to an elevation of $700 \mathrm{~m}$, and Mt. Psunj to $750 \mathrm{~m}$ (PRELOGOVIĆ, 1975). The uplift of the geological structures Mt. Prosara, Mt. Motajica and Mt. Vučjak, as well as the lowered structures between them (where the alluvial fans of the right Sava River tributaries were depo- sited), mark the area of northern Bosnia and Herzegovina (ŠPARICA et al., 1972b; 1983; 1987). Tectonic events during the Pliocene and Quaternary (HORVÁTH \& CLOETINGH, 1996; BADA et al., 1998) had a major influence on the recent structural pattern of the Slavonian mountains (ŠPARICA et al., 1987; PAVELIĆ, 2001). The same can be said for northern Bosnia and Herzegovina (ŠPARICA et al., 1972b; 1983; 1987). These movements are reflected in the geometry of the Quaternary aquifer system in the Sava River valley. They are visible in the crosssection through the Sava River valley (Fig. 6) in which the thickness of the Quaternary aquifer is clearly expressed. Two upthrown blocks were highlighted in the central part of the Sava River valley: near Slavonski Kobaš (borehole SK-1 at Fig. 6) and Bebrina, east of Slavonski Brod (borehole B-8 at Fig. 6). The upthrown block near Slavonski Kobaš is connected with the uplift of Mt. Motajica, and the upthrown block near Bebrina is connected with the uplift of Mt. Vučjak in Bosnia and Herzegovina. The aquifer system bedrock was detected at $24.5 \mathrm{~m}$ near Slavonski Kobaš and at $20 \mathrm{~m}$ east of Slavonski Brod.

The maximum thickness of the Quaternary aquifer was detected in the lowered structures between the upthrown blocks approximately $100 \mathrm{~m}$ in the area of the Lonjsko polje (borehole ML1-2 on Fig. 6), approximately $70 \mathrm{~m}$ in the area of Jasenovac (borehole B-8 on Fig. 6), approximately $60 \mathrm{~m}$ at Davor (borehole DZ-2 on Fig. 6), and over $150 \mathrm{~m}$ in the area of Migalovci (borehole BM-1 on Fig. 6) and Slavonski Brod (Fig. 6).

The alluvial aquifer in the fan-shaped area of the Vrbas River has a much greater distribution in Bosnia and Herzegovina (Fig. 5). In the wider area of the Vrbas River mouth where it meets the Sava River in northern Bosnia, the sediments of Pliocene age were registered at a depth of 256 to $355 \mathrm{~m}$, which means that the Lower Pleistocene sediments were deposited at a depth of less than $256 \mathrm{~m}$.

Deposits of the left tributaries of the Sava River (except for gravel and sand) often contain a considerable amount of silt and clay. The depth of such deposits in the valley of the Sloboština watercourse reaches a few tens of metres (wells B-26 at Fig. 9). Between the alluvial fan of the right tributaries of the Sava River and the left tributaries in the north of the Sava River valley, the Quaternary aquifer is poorly developed (Fig. 5). The permeable sandy layers are relatively rare and thin within semipermeable clay-silt Quaternary deposits (Fig. 10). They are often found at greater depths.

The maximum thickness of the sediments above the conditional marker Q' in eastern Slavonia was registered south of Đakovo and Vinkovci and east of Županja. The thickness reaches over 300 m (URUMOVIĆ et al., 1978). The evolutionary history of the structures was observed by comparing the thickness of these sediments with the thicknesses of older formations (PRELOGOVIĆ \& CVIJANOVIĆ, 1983); these observations show that the thick Quaternary sediments were deposited in a local structural depression.

The Middle Pleistocene sediments were detected by palaeontological investigation at a depth of 20 to 165 m (SOKAČ, 1976; URUMOVIĆ \& SOKAČ, 1974). West of Slavonski Brod, the Pleistocene deposits were not separated due to a lack of detailed palaeontological documentation. However, according to the number of the coarse-grained layers, which match the deposition in interstadial periods, An. SIMUNIC et al. (1973) assumed that the Middle Pleistocene occurred at depths of 40-120 m. The lower boundary of the Middle Pleistocene in eastern Slavonia is located 


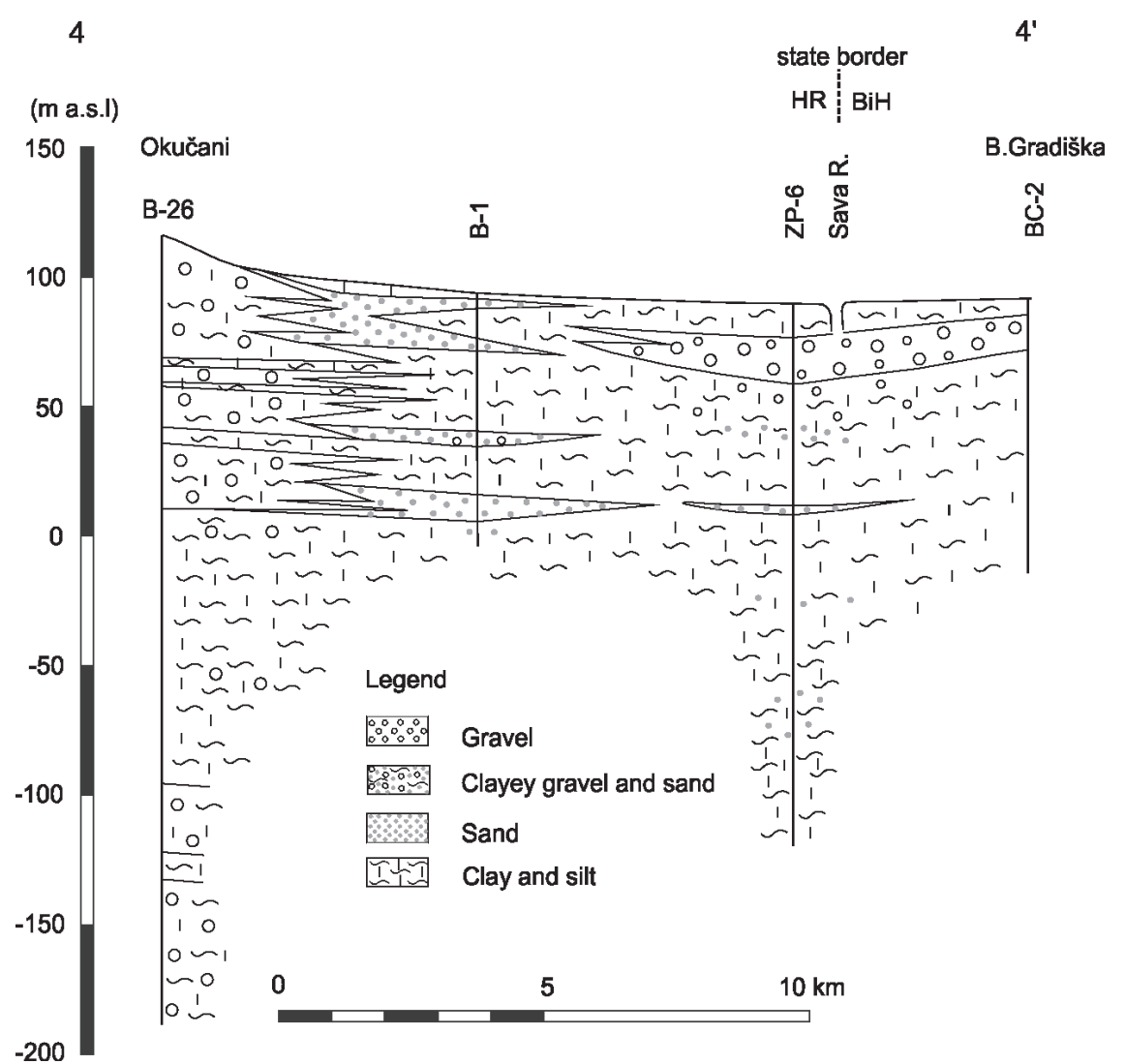

Figure 9. Lateral lithological cross-section of the Quaternary aquifer between B.Gradiška in Bosnia and Herzegovina and the Slavonian Mountains.

at a depth between 150 and $200 \mathrm{~m}$ (URUMOVIĆ et al., 1978). The bedrock sediments are composed of clay and sand.

The layers of the Middle Pleistocene have separated on the slopes of Mt. Fruška Gora and in the covered areas of the Srijem and southern Bačka (ČIČULIĆ-TRIFUNOVIC \& GALOVIĆ, 1983). In the southern Bačka, the Middle Pleistocene sediments were drilled beneath layers of the second Danube terrace at a depth of $25 \mathrm{~m}$. They are composed of sand, gravel and lesser amounts of sandy clay.

The shallowest aquifer in eastern Slavonia consists predominantly of coarse-grained material that was transported by the Bosna River (Fig. 5). The Riss-Würm interglacial period was proven by palaeontological investigation of the upper part of the gravelly aquifer close to the Sava River (MUTIĆ, 1993). The aquifer extends from the Sava River in the south to the VrpoljeCerna line in the north (MILETIĆ et al., 1986), and its depth is approximately $100 \mathrm{~m}$. The diameter of the gravel pebbles reaches $50 \mathrm{~mm}$ whereas medium-grained sand is composed of 1-2 $\mathrm{mm}$ diameter grains (URUMOVIĆ et al., 1978).

In the central and northern parts of the Slavonija-Srijem depression, the aquifers are composed predominantly of uniform medium-grained sand with particle diameters of 0.1 to $0.3 \mathrm{~mm}$ (URUMOVIĆ et al., 1978). Within the sand, there are smaller gravel pebbles with a diameter of less than $4 \mathrm{~mm}$. Within an approximately $200 \mathrm{~m}$ thick succession of sediments, there can be 2 to 11 sand layers (BAČANI et al., 1999). According to the lithological and well-logging data, six to seven sandy layers could be selected north of Županja (boreholes V-1 and V-2 on Fig. 6).

In the area of Đakovo-Vinkovci and the Vukovar plateau, the hydrogeological conditions are somewhat different. A few sandgravel aquifers were deposited below the thick loess (boreholes
B-1 on Fig. 11). The thickness of the loess above the aquifer can be greater than $60 \mathrm{~m}$.

Research conducted on the sediments' age shows the difficulties in defining the chronostratigraphic divisions. Pleistocene

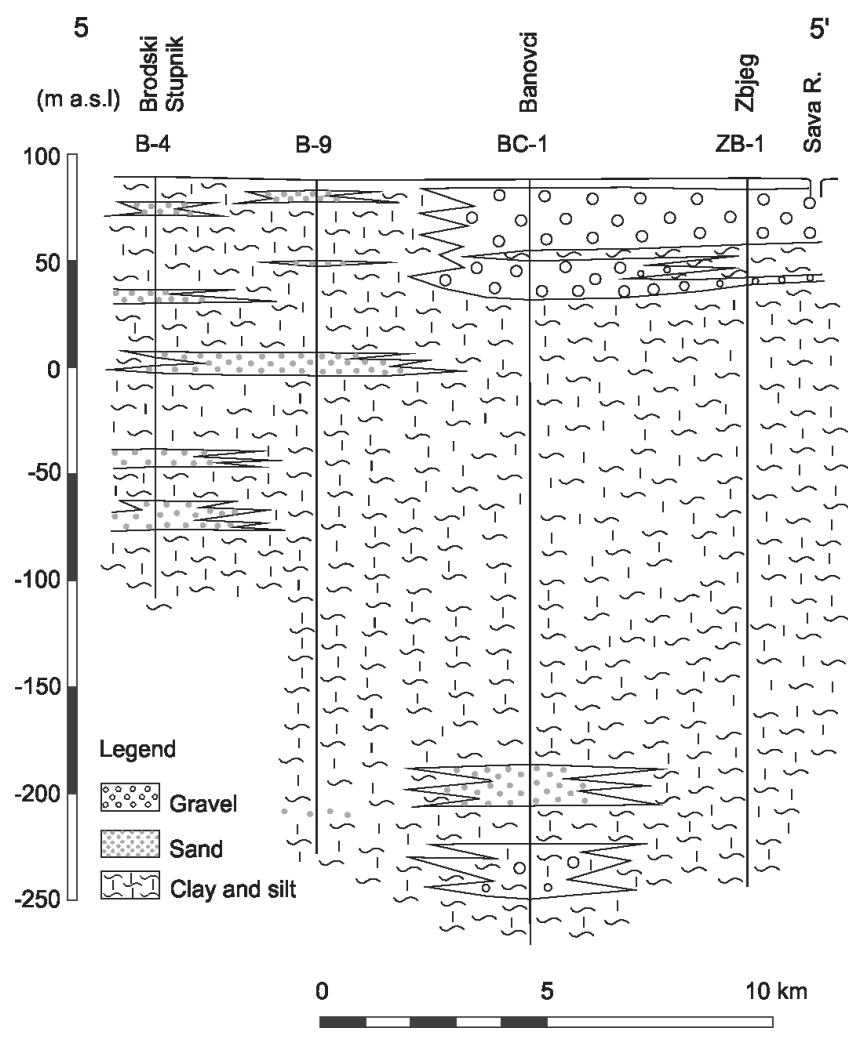

Figure 10. Lateral lithological cross-section of the Quaternary aquifer between the Sava River and Brodski Stupnik. 


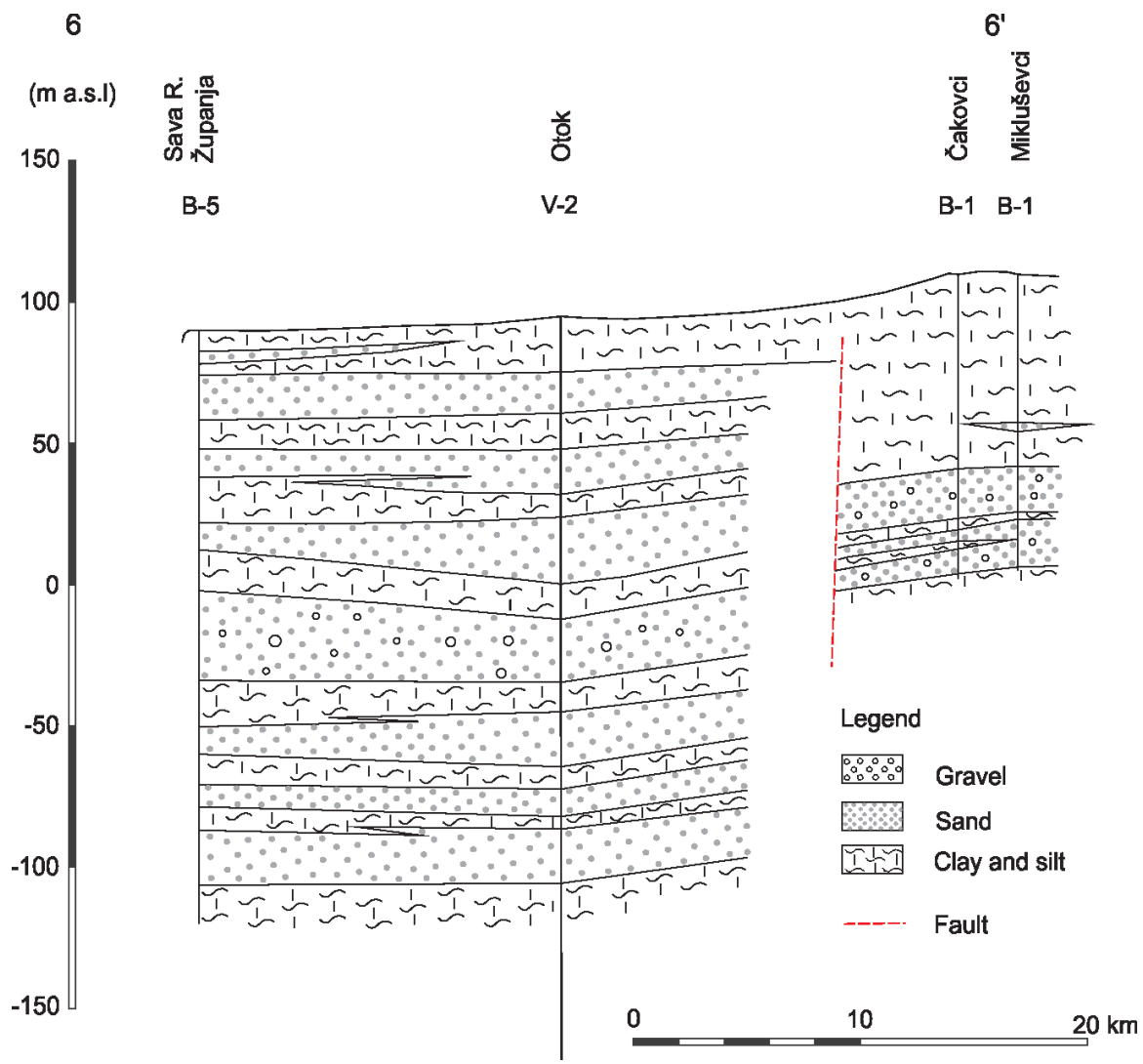

Figure 11. Lithological cross-section of the Quaternary aquifer between Županja and Vukovar plateau.

deposits were mostly separated on the basis of palaeontological analysis. According to SOKAČ (1978), the most important forms are a genus of ostracods Scottia, Ilyocypris and Condona, and particular species including Scottia tumida, Scottia browniana, Ilycypris slavonica, Condona neglecta, Cytherissa lacustris and others. Most of these fossils were widespread throughout the whole Quaternary, but some were also found in the Pliocene. In addition to the palaeontological analysis, a division of the Pleistocene is based on climatological characteristics. According to ŠEGOTA (1963), the pluvial maximum was in the Gunz, and the post-Gunz phase belongs to the recession phase of the Pleistocene glaciation, during which the intensity of pluvials gradually decreased. Each glacial period was shorter than the previous one, and Šegota concluded that it can be expected that the volume of material accumulated in the Riss was higher than in the Würm, in the Mindel higher than in the Riss, etc. The accumulated volume is proportional to the periods' durations.

It has already been stated that deposits at depths greater than $75 \mathrm{~m}$ southeast of Zagreb have been classified by some authors as Middle Pleistocene in age (SOKAČ, 1978; HERNITZ et al., 1981) and by others as representing the Upper Pleistocene (An. ŠIMUNIĆ \& BASH, 1975; Al. ŠIMUNIĆ et al., 1988). If the sedimentation occurred as interpreted by ŠEGOTA (1963), the assumptions about the various stages of Würm glaciation southeast of Zagreb as interpreted by An. ŠIMUNIĆ \& BASH (1975) and Al. ŠIMUNIĆ et al. (1988) are questionable. Based on the number of gravel layers, these authors believe that the thickness of the Upper Pleistocene (with the Holocene) is approximately 75 metres. They have also stated that layers representing cyclic sedimentation can be observed in the vertical plan. The gravel-sand layers were deposited by the rivers in a warm climate and oxidative conditions (during an interstadial period), while the layers of fine-grained sediments were deposited in the marsh areas in a cold climate and reductive conditions (during a stadial period). However, cyclic sedimentation also occurred during the Middle Pleistocene. River flow, which was the main transporter of the clastic material, was losing energy, as manifested by the deposition of fine-grained sediments. In this case, it would be more realistic to accept the opinion of SOKAC (1978) and HERNITZ et al. (1981), who concluded that the deposits of the Upper Pleistocene southeast of Zagreb are thin and that the Upper Pleistocene and Holocene sediments reach a thickness of barely $20 \mathrm{~m}$. This conclusion was proven by the findings of Candona ostracods (Candona candida, C. neglecta, C. weltneri, C. marchica) (SOKAČ, 1978). Sokač stated that unlike the Middle Pleistocene deposits, which are rich with forms of Scotti, in the Upper Pleistocene deposits, these fossils are very rare. In other areas of northern Croatia, the Upper Pleistocene sediments, often together with Holocene sediments, were observed at a depth of 20-30 m (URUMOVIĆ \& SOKAČ, 1974; SOKAČ, 1976; ČIČULIĆTRIFUNOVIĆ \& GALOVIĆ, 1983) and 30-40 m (An. ŠIMUNIĆ et al., 1973; BABIĆ et al., 1978; URUMOVIĆ et al., 1978).

Quaternary aquifers are mostly overlain by marshy sediments that were formed during the Upper Pleistocene and Holocene. These overlying deposits above aquifers are semipermeable and, with regard to their hydrogeological function, are considered to be an aquitard. At the extreme west of the Sava River valley, the aquitard belongs to flood facies of the Sava River and is of Holocene age. Downstream from Sisak, the aquitard belongs to flood facies of the Sava River as well as lake-marsh facies of Holocene age, below which was deposited in the marsh loess of Upper Pleistocene age. Tectonic movements led to the uplift of the Vinkovci area so that the continental loess was partially deposited (GALOVIĆ \& MUTIĆ, 1984; MUTIĆ, 1990). 
The aquitard can reach a thickness of more than $50 \mathrm{~m}$. In the uttermost western part of the Sava River valley, the aquitard is very thin and is often missing. Downstream, its thickness increases and in some places reaches more than $20 \mathrm{~m}$ - in eastern Slavonia, sometimes even more than $40 \mathrm{~m}$ (Fig. 12a). Generally, an aquitard is composed of clay, silt and fine-grained sand. Unlike the aquitard above the Drava aquifer, clay is the dominant component in the shallow parts of the covering aquitard in the Sava River valley (Fig. 12b). This is especially pronounced in the western and central parts of the valleys.

\subsection{The Sava River valley - a regional groundwater resource}

In the wider Zagreb area, the average hydraulic conductivity of the gravel-sand aquifer is extremely high (Fig. 5). West of the geological structure Podsusedski prag, the hydraulic conductivity of the aquifer reaches $3400 \mathrm{~m} /$ day. East of Zagreb, it decreases to approximately $2000 \mathrm{~m} /$ day. Near the geological structure Sisački prag, sand becomes the dominant material in the composition of the aquifer (Fig. 6), and the average hydraulic conduc-
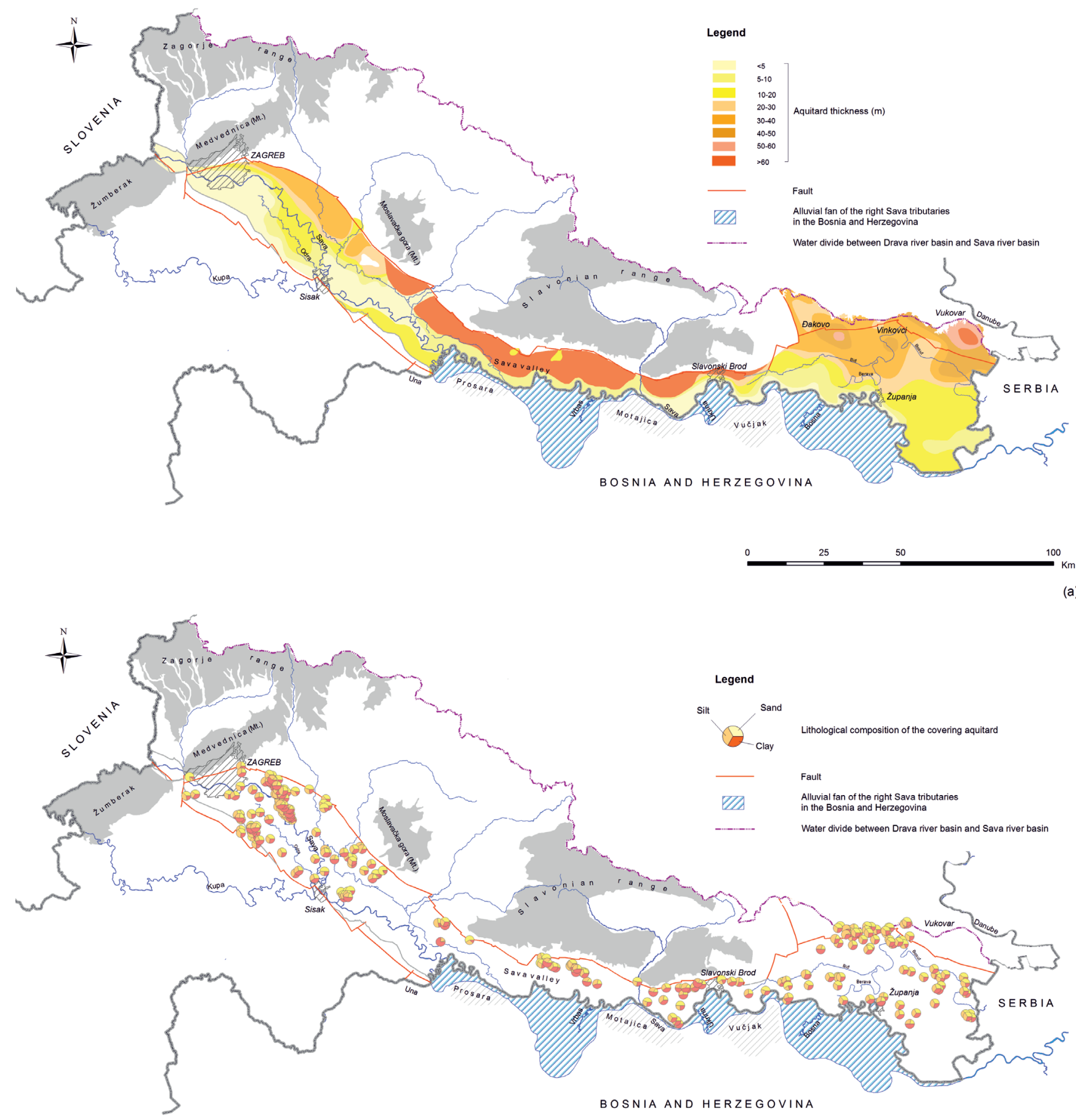

\begin{tabular}{lll}
0 & 50 & 100 \\
\hline
\end{tabular} 
tivity of the aquifer is reduced to less than $50 \mathrm{~m} /$ day. Within the aquifer, there are several permeable layers that are separated by low-permeability clay-silt layers. These layers in some places are missing, which has caused the formation of a unique hydraulic aquifer with expressed heterogeneity and anisotropy.

In the wider Zagreb area, the Sava riverbed cuts into the aquifer, and the water in the river is hydraulically connected to the groundwater in the aquifer. The groundwater is drained by the Sava River during most of the year. In the area of the geological structure Podsusedski prag, due to the narrowing of the alluvion, the groundwater flows to the Sava River. Approximately $10 \mathrm{~km}$ downstream from the Podsusedski prag, in the central part of the Zagreb area, on the right bank, groundwater is recharged by the Sava River at low- and high-water levels (Fig. 5). The main cause of the groundwater recharge by the Sava River in this area is groundwater abstraction at the Zagreb pumping sites. Downstream from the City of Zagreb, the hydraulic image changes, and groundwater flows into the Sava River. Between Zagreb and Sisak, discharge of groundwater to the surface is a widespread phenomenon that is especially pronounced during long-term highwater levels. It is caused by the inflow of groundwater in a neotectonic depression where the piezometer levels exist above ground level. Groundwater is discharged to the Odra, a left tributary of the Kupa River. The Odra flows between Vukomeračke Gorice and the Sava River. It is recharged by groundwater that flows from Vukomeračke Gorice and groundwater that flows from the southeastern part of Zagreb.

Downstream from Sisak, in the area of the Lonjsko polje, the average hydraulic conductivity of the sandy aquifer is approximately $50 \mathrm{~m} /$ day. Towards the northern and the southern boundaries of the Sava River valley, it decreases to less than $10 \mathrm{~m} /$ day. In the alluvial fan of the Una River, the average hydraulic conductivity of the gravel-sand aquifer reaches $100 \mathrm{~m} /$ day; in the alluvial fan of the Vrbas River, it is approximately $200 \mathrm{~m} /$ day; and in the alluvial fan of the Ukrina River, it reaches 170 m/day (Fig. 5). The lower values of the average hydraulic conductivity can be found at the northernmost edge of the aquifer as a result of smaller particle size and higher content of finer sediments. Deeper aquifers, which lie at depths greater than $60 \mathrm{~m}$ (Figs. 9 and 10), also have lower values of their hydrogeological parameters. The maximum of their average hydraulic conductivity reaches $10 \mathrm{~m} /$ day.

The average hydraulic conductivity of the gravel-sand aquifer that belongs to the alluvial fan of the Bosna River reaches 170 $\mathrm{m} /$ day (Fig. 5). The average hydraulic conductivity of the sandy aquifer in the central and northern parts of the Slavonia-Srijem basin varies from 4 to $13 \mathrm{~m} /$ day in the deeper aquifers to approximately $30 \mathrm{~m} /$ day in the shallow aquifer.

Downstream from Sisak, measurements of the groundwater level have not been established. Occasional measurements of the groundwater levels at several locations in the Lonjsko polje area and eastern Slavonia show that groundwater flows towards the Sava River during most of the year (BRKIĆ et al., 2013; 2016) (Fig. 5). Recharge from the river occurs during the high water levels and lasts a relatively short time. The main source of the aquifer recharge is the infiltration of precipitation through the covering aquitard, while draining of the aquifer is caused by evapotranspiration and groundwater discharge to the watercourses.

The Bosut River in eastern Slavonia was formed much like the Odra River in the western part of the Sava River valley. The Sava River flows through hypsometrically higher terrain in relation to its hinterland. Due to the thinness of the covering aquitard in some places along the Sava River, the riverbed cuts into the aquifer, thus achieving direct communication between the river and groundwater (BRKIĆ et al., 2016). The piezometer level is held by the Sava water stage. It can be higher than the terrain in the hinterland, especially during very high waters. The Berava stream has formed by the groundwater discharge to the surface. Its extension the Bosut River still flows on the aquitard, and direct contact with groundwater is significantly weakened.

In the area of the Đakovo-Vinkovci plateau, below a 20-30 $\mathrm{m}$ thick loess deposit, the sandy aquifer is registered. The aquifer transmissivity, according to existing data, reaches $150 \mathrm{~m}^{2} /$ day. The relatively thick sand aquifer with transmissivity of 300-400 $\mathrm{m}^{2}$ /day was drilled in the Vinkovci area. Good hydrogeological properties of the aquifer at the Vukovar plateau were determined in the area from Čakovci to Mikluševci (Figs. 5 and 11). Based on the test pumping wells in Čakovci and Mikluševci, the aquifer transmissivity was determined to be of 360 and $550 \mathrm{~m}^{2} /$ day, respectively. Artesian aquifers were registered in the lowlands of the Đakovo area and are a result of the position of the piezometric levels.

\section{CONCLUSION}

Two principal topographic features of the study area represent the surface expression of the geological framework - the mountains on the north and south sides of the valley and the narrow valley between them. The mountains consist of sedimentary, magmatic, and metamorphic rocks. The valley is filled with unconsolidated to moderately consolidated deposits. These sediments are mostly material that was eroded from the surrounding bedrock mountains and mountains in the catchment area of the Sava River.

Nearly all important drinking groundwater that comes from this area is transmitted and stored in the youngest sediments of the valley fill, which are from the Quaternary age. The bedrock that surrounds and underlies the valley fill is apparently impermeable.

The structural configuration of the aquifer system bedrock beneath the Sava River valley outlines the extent and depth of the valley fill and therefore affects the movement and storage of groundwater. The aquifer system bedrock beneath the valley is a narrow basin, divided into several inter-connected structural basins.

It is important to highlight the existence of a series of uplifted and lowered geological structures that are the results of the compression of the basin area. Faults extend along the geological structures.

The sedimentary depositional systems were formed between two upthrown blocks, Podsusedski and Sisački prag. Downstream from Sisak, two upthrown blocks were highlighted: near Slavonski Kobaš and Bebrina, and east of Slavonski Brod. Podsusedski prag is connected with the uplift of the ŽumberakMedvednica structural unit. Sisački prag is situated along the southern boundary of the Sava River basin. The upthrown block near Slavonski Kobaš is connected with the uplift of Mt. Motajica, and the upthrown block near Bebrina is connected with the uplift of Mt. Vučjak in Bosnia and Herzegovina.

The deepest part of the Quaternary aquifer system bedrock was detected between Zagreb and Sisak, and is more than $200 \mathrm{~m}$ below the land surface. East of Slavonski Brod in Slavonia, it was also registered at a depth of $200 \mathrm{~m}$ below the land surface. Between these lowered structures, the aquifer system bedrock was detected at much lower depths $-8 \mathrm{~m}$ at the Sisački prag, $24.5 \mathrm{~m}$ 
near Slavonski Kobaš and 20 m east of Slavonski Brod. The aquifer system bedrock was registered at a maximum depth of $100 \mathrm{~m}$ below the land surface in the Lonjsko polje between Sisak and Slavonski Kobaš.

The Quaternary aquifer system is mostly composed of alluvial sediments from the Sava River and watercourses existing before the occurrence of the Sava River in the western part of the valley as well as of alluvial sediments that were transported by the right tributaries of the Sava River and which belong to the alluvial fans in the eastern part of the valley.

The best hydrogeological properties of the aquifer system were registered in the vicinity of the Sava River, so all large pumping sites are located close to the river. In many places, the Sava riverbed cuts into the aquifer, and induced inflow from the river can be enabled.

The groundwater flow direction is from the valley margins towards the Sava River. The main source of groundwater recharge is infiltration of precipitation. Groundwater discharge occurs primarily through the Sava River and evapotranspiration and, to a much lesser extent, through pumping. Such conceptualization of the aquifer system can serve as the physical and hydraulic basis for a future numerical evaluation of the regional hydrogeological system.

\section{ACKNOWLEDGEMENT}

The research was conducted within the project „Basic Hydrogeological Map of the Republic of Croatia" which was financed by the Ministry of Science, Education and Sports, Republic of Croatia. The author is grateful to the editor and reviewers for the careful review of the article. Their useful comments and suggestions have helped to improve the manuscript.

\section{REFERENCES}

BABIĆ, Ž., ČAKARUN, I., SOKAČ, A. \& MRAZ, V. (1978): O geologiji kvartarnih naslaga porječja rijeke Drave [About the geology of Quaternary deposits of the Drava river basin - in Croatian].- Geol. vjesnik, 30/1, 43-61.

BAČANI, A. ŠPARICA, M. \& VELIĆ, J. (1999): Quaternary Deposits as the Hydrogeological System of Eastern Slavonia.- Geol. Croat., 52/2, 141-152. doi: 10.4154/ GC.1999.12

BADA, G., CLOETINGH, S., GERNER, P. \& HORVÁTH, F. (1998): Sources of recent tectonic stress in the Pannonian region: inferences from finite element modelling.Geophys. Int., 134, 87-101.

BRKIĆ, Ž., BRIŠKI, M. \& MARKOVIĆ, T. (2016): Use of hydrochemistry and isotopes for improving the knowledge of groundwater flow in a semiconfined aquifer system of the Eastern Slavonia (Croatia).- Catena, 142, 153-165. doi: 10.1016/j.catena.2016.03.010

BRKIĆ, Ž., URUMOVIĆ, K. \& BRIŠKI, M. (2013): Post audit analysis of a groundwater level prediction model in developed semiconfined aquifer system.- Water Resour. Manag., 27/9, 3349-3363. doi: 10.1007/s11269-013-0351-y

BRKIĆ, Ž., LARVA, O. \& URUMOVIĆ, K. (2010): Quantity status of groundwater in alluvial aquifers in northern Croatia.- Geol. Croat., 63/3, 283-298. doi: 10.4154/ GC. 2010.23

BRKIĆ, Ž. \& BIONDIĆ, B. (2000): Savski vodonosnik i njegove hidrogeološke značajke. [Sava aquifer and its hydrogeological characteristics - in Croatian].Zbornik radova, Okrugli stol: Hidrologija i vodni resursi Save u novim uvjetima, Slavonski Brod, 217-228.

CAPAR, A., BAČANI, A. \& MILETIĆ, P. (1994): Hidrogeološka obilježja porječja Save od Dugog Sela do Slavonskog Broda [Hydrogeological characteristics of the Sava catchment area from Dugo Selo to Slavonski Brod - in Croatian].- Hrvatske vode, $2 / 6,375-386$

CRNKOVIĆ, B. \& BUŠIĆ, M. (1970): Mineraloško-petrografski sastav nanosa rijeke Save [Mineralogical and Petrological composition of the Sava River sediment - in Croatian].- Zbornik radova RGN fak. Sveuč. u povodu 30 g. rada (1939-1969), $133-140$.

CSONTOS, L., NAGYMAROSY, A., HORVÁTH, F. \& KOVÁCS, M. (1992): Tertiary evolution of the Intra-Carpathian area: a model.- Tectonophysics, 208, 221-241. doi: 10.1016/0040-1951(92)90346-8
ČIČULIĆ-TRIFUNOVIĆ, M. \& GALOVIĆ, I. (1983): Osnovna geološka karta SFRJ 1:100 000. Tumač za list Bačka Palanka L34-99 [Basic Geological Map of SFRY 1:100000, Geology of the Bačka Palanka sheet - in Croatian].- Geološki institut Beograd i Geološki zavod Zagreb, Savezni geološki zavod, Beograd, 46 p.

DECKER, K. \& PERESSON, H. (1996): Tertiary kinematics in the Alpine-CarpathianPannonian system: links between thrusting, transform faulting and crustal extension.- In: WASSELY, G. \& LIEBL, W. (eds): Oil and Gas in Alpidic Thrustbelts and Basins of Central and Eastern Europe. EAGE Spec. Publ., 5, 69-77.

GALOVIĆ, I. \& MUTIĆ, R. (1984): Gornjopleistocenski sedimenti istočne Slavonije (Hrvatska) [Upper Pleistocene sediments of Eastern Slavonia (Croatia) - in Croatian].- Rad Jugosl. akad. znan. umjet., 411 (Razr. prir. znan., 20), 299-356, Zagreb.

HERNITZ, Z. (1983): Dubinski strukturno-tektonski odnosi u području istočne Slavonije. [Deep structural-tectonic relations in the area of Eastern Slavonia - in Croatian].- PhD Thesis, Jugosl. Komitet svjet. Kongr. za naftu, Nafta, 221 p.

HERNITZ, Z., KOVAČEVIĆ, S., VELIĆ, J., ŽELJKO, B. \& URLI, M. (1981): Primjer kompleksnih geološko-geofizičkih istraživanja kvartarnih naslaga u oklici Prevlake [Example of the complex geological-geophysical studies of the Quaternary deposits around Prevlaka - in Croatian].- Geol. vjesnik, 33, 11-34.

HOLLETT, K.J., DANSKIN, W.R., McCAFFREY, W.F. \& WALTI, C.L. (1991): Geology and Water Resources of Owens Valley, California.- USGS Water-Supply Paper 2370-B.

HORVÁTH, F. (1993): Towards a mechanical model for the formation of the Pannnonian basin.- Tectonophysics, 226, 333-357.

HORVÁTH, F. \& CLOETINGH, S. (1996): Stress-induced late stage subsidence anomalies in the Pannonian basin.- Tectonophysics, 266, 287-300. doi: 10.1016/ S0040-1951(96)00194-1

JAMIČIĆ, D. (1983): Strukturni sklop metamorfnih stijena Krndije i južnih padina Papuka [Structural fabric of the metamorphosed rocks of Mt. Krndija and the eastern part of Mt. Papuk - in Croatian].- Geol. vjesnik, 36, 51-72.

JAMIČIĆ, D. (1995): The role of sinistral strike-slip faults in the formation of the structural fabric of the Slavonian Mts. (Eastern Croatia).- Geol. Croatica, 48/2, 155160. doi: $10.4154 / \mathrm{GC} .1995 .12$

KÁZMER, M. \& KOVÁCS, S. (1985): Permian-Paleogene paleogeography along the eastern part of the Insubric-Periadriatic Lineament system: evidence for continental escape of the Bakony-Drauzug.-Acta Geol. Hung., 28, 71-84.

MAGAŠ, N. (1986): Osnovna geološka karta SFRJ 1:100 000. Tumač za list Osijek L34-86. [Basic Geological Map of SFRY 1:100000, Geology of the Osijek sheet - in Croatian].- Geološki zavod Zagreb, Savezni geološki zavod, Beograd, 54 p.

MÁRTON, E., PAVELIĆ, D., TOMLJENOVIĆ, B., PAMIĆ, J. \& MÁRTON, P. (1999): First paleomagnetic results on Tertiary rocks from the Slavonian Mountains in the Southern Pannonian Basin, Croatia.- Geol. Carpathica, 50, 273-279.

MILETIĆ, P., BAČANI, A., MAYER, D. \& CAPAR, A. (1986): Prilog poznavanju hidrogeoloških značajki prve hidrogeološke zone na području istočne Slavonije [Contribution to the knowing of the hydrogeological characteristics of the first hydrogeological zone in Eastern Slavonia - in Croatian].- Geol. vjesnik, 39, 137150.

MUTIĆ, R: (1990): Korelacija kvartara istočne Slavonije na osnovi podataka mineraloško-petrografskih analiza (Istočna Hrvatska, Jugoslavija). Dio II: Lesni ravnjak [Correlation of the Quaternary sediments in the Eastern Slavonia on the basis of mineralogical and petrographic data (Eastern Croatia, Yugoslavia). Part II: Loess plateau - in Croatian].- Acta geol., 20/2, 29-80, Zagreb.

MUTIĆ, R: (1993): Korelacija kvartara istočne Slavonije na osnovi podataka mineraloško-petrografskih analiza (Istočna Hrvatska, Jugoslavija). Dio III: SlavoniaSrijem basin [Correlation of the Quaternary sediments in the Eastern Slavonia on the basis of mineralogical and petrographic data (Eastern Croatia, Yugoslavia). Part III: Slavonsko - in Croatian].-Acta geol., 23/1, 1-37, Zagreb.

PAVELIĆ, D. (2001): Tectonostratigraphic model for the North Croatian and North Bosnian sector of the Miocene Pannonian Basin System.- Basin Research, 12, 359 376. doi: 10.1046/j.0950-091x.2001.00155.x

PERESSON, H. \& DECKER, K. (1997): Far-field effects of Late Miocene subduction in the Eastern Carpathians: E-W compression and inversion of structures in the AlpineCarpathian-Pannonian region.- Tectonics, 16/1, 38-56. doi: 10.1029/96TC02730

PRELOGOVIĆ, E. (1975): Neotektonska karta SR Hrvatske [Neotectonic map of the SR Hrvatska - in Croatian].- Geol. vjesnik, 28, 97-108.

PRELOGOVIĆ, E. \& CVIJANOVIĆ, D. (1983): Prikaz neotektonske aktivnosti dijela Slavonije, Baranje i Bačke [Neotectonic activity of a part of Slavonia, Baranja and Bačka - in Croatian].- Geol. vjesnik, 36, 241-254, Zagreb.

PRELOGOVIĆ, E., JAMIČIĆ, D., ALJINOVIĆ, B., SAFTIĆ, B. \& VELIĆ, J. (1995): Dinamika nastanka struktura južnog dijela Panonskog bazena [The dynamics of the formation of structures of the southern part of the Pannonian Basin - in Croatian].- In: VLAHOVIĆ, I., VELIĆ I. \& ŠPARICA, M. (eds): 1. Hrvatski geološki kongres, Zbornik radova, 481-486.

PRELOGOVIĆ, E., SAFTIĆ, B., KUK, V., VELIĆ, J., DRAGAŠ, M. \& LUČIĆ, D. (1998): Tectonic activity in the Croatian part of the Pannonian basin.- Tectonophysics, 297, 283-293. doi: 10.1016/S0040-1951(98)00173-5 
RATSCHBACHER, L. (1991): Lateral extrusion in the Eastern Alps, part I. Boundary conditions and experiments scaled for gravity.- Tectonics, 10, 245-256. doi: 10.1029/90TC02622

ROYDEN, L., HORVÁTH, F. \& RUMPLER, J. (1983): Evolution of the Pannonian Basin system. 1. Tectonics.- Tectonics, 2/1, 63-90. doi: 10.1029/TC002i001p00063

ROYDEN, L.H. \& HORVÁTH, F. (Eds.) (1988): The Panonian Basin. A Study in Basin Evolution.-Am. Assoc. Pet. Geol. Mem., 45

SOKAČ, A. (1978): Pleistocene ostracode fauna of the Panonian basin in Croatia.- Paleont. Jugosl., 20, 1-51.

SOKAČ, A. (1976): Pleistocenska fauna ostrakoda iz nekih bušotina u istočnoj Slavoniji (sjeverna Hrvatska) [The Pleistocene fauna of Ostracoda from some wells in Eastern Slavonia (northern Croatia) - in Croatian].- Geol. vjesnik, 29, 159-172.

STEGENA, J., GECZY, B. \& HORVÁTH, F. (1975): Late Cenozoik evolution of the Pannonian Basin.- Tectonophysics, 26, 71-90.

ŠEGOTA, T. (1963): Geografske osnove glacijala [Geographical base of the glacial - in Croatian].- Radovi geograf. instituta, 4, 1-119.

ŠIKIĆ, K. (1995): Prikaz geološke građe Medvednice [Overview of geolocical structure of the Medvednica Mt. - in Croatian].- In: ŠIKIĆ, K. (ed.): Geološki vodič Medvednice, 7-40.

ŠIMUNIĆ, AL., NOVOSEL-ŠKORIĆ, S. \& PILJUROVIĆ, LJ. (1988): Litološka korelacija i kronostratigrafsko razgraničavanje kvartarnih naslaga na lokalitetu Prevlaka jugoistočno od Zagreba [Lithological correlation and chronostratigraphic delimitation of Quaternary sediments at the location Prevlaka southeast of Zagreb - in Croatian].- Geol. vjesnik, 41, 167-179.

ŠIMUNIĆ, AN. \& BASCH, O. (1975): Stratigrafija kvartarnih sedimenata Zagrebačkog Posavlja [The stratigraphy of Quaternary sediments in the Zagrebačko Posavlje - in Croatian].- Geol. vjesnik, 28, 153-164.

ŠIMUNIĆ, AN., ŠPARICA, M. \& ŠIMUNIĆ, AL. (1973): Kvartarne naslage na području Slavonski Brod-Staro Petrovo selo [Quaternary sediments in the area of Slavonski Brod - Staro Petrovo selo - in Croatian].- Geol. vjesnik, 26, 73-82.

ŠPARICA, M. (1987): Osnovna geološka karta SFRJ 1:100.000. List Slavonski Brod L34-97. - Geol. zavod Zagreb \& Geoinženjering Sarajevo (1986), Sav. geol. zavod, Beograd.

ŠPARICA, M., BUZALJKO, R. \& PAVELIĆ, D. (1987): Osnovna geološka karta SFRJ 1:100.000. Tumač za list Slavonski Brod L34-97.- Geol. zavod Zagreb \& Geoinženjering Sarajevo (1986), Sav. geol. zavod, Beograd, 56 p.

ŠPARICA, M. \& PAMIĆ, J. (1986): Prilog poznavanju tektonike Požeške gore. [Contribution to the knowing of the Požeška gora tectonic - in Croatian].- Rad JAZU, 21, 85-96.

ŠPARICA, M., BUZALJKO, R. \& JOVANOVIĆ, Č. (1983): Osnovna geološka karta SFRJ 1:100.000. List Nova Gradiška L33-107.- Geol. zavod Zagreb \& Geoinženjering Sarajevo (1983), Sav. geol. zavod, Beograd.

ŠPARICA, M. \& BUZALJKO, R. (1984): Osnovna geološka karta SFRJ 1:100.000. Tumač za list Nova Gradiška L33-107.- Geol. zavod Zagreb \& Geoinženjering Sarajevo (1983), Sav. geol. zavod, Beograd, 54 p.
ŠPARICA, M., JURIŠA, M., CRNKO, J., ŠIMUNIĆ, A., JOVANOVIĆ, Č. \& ŽIVANOVIĆ, D. (1972a): Osnovna geološka karta SFRJ 1:100.000. List Nova Kapela L33-108.- Geol. zavod Zagreb \& Institut za geologiju Sarajevo (1972), Sav. geol. zavod, Beograd.

ŠPARICA, M., JURIŠA, M., CRNKO, J., ŠIMUNIĆ, A., JOVANOVIĆ, Č. \& ŽIVANOVIĆ, D. (1972b): Osnovna geološka karta SFRJ 1:100.000. Tumač za list Nova Kapela L33-108.- Geol. zavod Zagreb \& Institut za geologiju Sarajevo (1972), Sav. geol. zavod, Beograd, 55 p.

TARI, V. \& PAMIĆ, J. (1998): Geodynamic evolution of the northern Dinarides and the southern part of the Pannonian Basin.- Tectonophysics, 297, 269-281. doi: 10.1016/S0040-1951(98)00172-3

URUMOVIĆ, K. \& MIHELČIĆ, D. (2000): Podzemne vode savskog vodonosnika. [Groundwater of the Sava aquifer - in Croatian].- Zbornik radova, Okrugli stol: Hidrologija i vodni resursi Save u novim uvjetima, Slavonski Brod, 205-215.

URUMOVIĆ, K., HLEVNJAK, B., TADIĆ, Z. \& PETROVIĆ, M. (1994): Zalihe podzemnih voda dravskog kvartarnog vodonosnika i mogućnosti korištenja [Groundwater resources of the Quaternary aquifer in the Drava River valley and possibility of exploitation - in Croatian].- Priopćenja sa Znan.skupa: „Poljoprivreda i gospodarenje vodama“, Bizovačke toplice, 425-433.

URUMOVIĆ, K., HERNITZ, Z. \& ŠIMON, J. (1978): O kvartarnim naslagama istočne Posavine [About Quaternary sediments of Eastern Posavina - in Croatian].-Geol. vjesnik, 30/1, 297-308.

URUMOVIĆ, K., HERNITZ, Z., ŠIMON, J. \& I VELIĆ, J. (1976): O propusnom mediju kvartarnih, te gornjo i srednjepliocenskih naslaga sjeverne Hrvatske [About permeable medium of the Quaternary, Upper and Middle Pliocen's deposits in the northern Croatian - in Croatian].-Zbornik radova 4. jug. simp. o hidrogeol. i inž. geol., knjiga 2, 395-410.

URUMOVIĆ, K. \& SOKAČ, A. (1974): O kvartarnim naslagama Županje [About Quaternary sediments of Županja - in Croatian].- Geol. vjesnik, 27, 319-330.

VELIĆ, J. (1983): The neotectonic relations and development of the western part of the Sava river depression (in Croatian).- Acta Geol. Jugosl. akad. znan. umjet., 13/2, 26-65.

VELIĆ, J. \& SAFTIĆ, B. (1996): Dubinskogeološki odnosi područja smetlišta „Jakuševec" - čimbenik sanacije [Subsurface geological relations in the area of „Jakuševec” dump - a solving factor - in Croatian].- Proceedings of the IVth International Symposium „Waste management - Zagreb '96”, Zagreb, 197-205.

VELIĆ, J. \& DURN, G. (1993): Alternating lacustrine-marsh sedimentation and subaerial exposure phases during Quaternary: Prečko, Zagreb, Croatia.- Geol. Croatica, 46/1, 71-90. doi: 10.4154/GC.1993.06

VELIĆ, J. \& SAFTIĆ, B. (1991): Potpovršinska rasprostranjenost i facijesne značajke srednjopleistocenskih taložina u području između Zaprešića i Samobora.- Geol. vjesnik, 44, 78-82.

VIDAČEK, Ž., BOGUNOVIĆ, M., HUSNJAK, S., SRAKA, M., BENSA, A. \& PETOŠIĆ, D. (2002): Hidropedološka karta Republike Hrvatske 1:300.000. Vodno područje sliva Save [Hydropedological map of the Republic of Croatia, Sava River Basin - in Croatian]. 
